\title{
Structural Evidence For Extensional Domain-Type Geothermal Play In Western Anatolia: A Case Study From Afyon-Akşehir Graben
}

\author{
Çağlar ÖZKAYMAK ${ }^{1-2 *}$, Hasan SÖZBiLiR ${ }^{3-4}$ \\ ${ }^{1}$ Afyon Kocatepe University, Department of Geological Engineering, Afyonkarahisar, Turkey. \\ ${ }^{2}$ Earthquake Research and Implementation Center of Afyon Kocatepe University, Afyonkarahisar, Turkey. \\ ${ }^{3}$ Dokuz Eylül University, Department of Geological Engineering, izmir, Turkey. \\ ${ }^{4}$ Earthquake Research and Implementation Center of Dokuz Eylül University, Izmir, Turkey.
}

Sorumlu yazar*e-posta: activetectonics@gmail.com ORCID ID: https://orcid.org/0000-0002-0377-1324 e-posta: hasan.sozbilir@gmail.com ORCID ID: https://orcid.org/0000-0002-3777-4830

Geliş Tarihi: 16.03.2020 Kabul Tarihi: 28.07.2020

Keywords

Afyon Akşehir Graben; Geothermal play type; Extensional domain; Western Anatolia

\begin{abstract}
Afyon-Akşehir Graben (AAG) which consists of the southeastern part of Akşehir-Simav Fault System (ASFS) is one of the active depression areas in Western Anatolia. The western sector of the NW-SEtrending AAG is controlled by many active normal fault segments, namely Erkmen, Gecek, and Gazlıgöl Faults. Two main geothermal fields namely, Ömer-Gecek and Gazlıgöl contain reservoirs of fluid with temperatures up to $130^{\circ} \mathrm{C}$, are located on the junction points of Gecek-Erkmen faults and GazlıgölYarımca faults, respectively. The area contains three unconformity bounded geological units; Mesozoic rocks of the Afyon Metamorphic Zone (reservoir unit), Miocene volcano-sedimentary succession (cover unit), including several sedimentary and volcanic units and Quaternary modern basin-fills of alluvial, fluvial and travertine deposits. This study involves use of geological mapping and structural geology methods to identify play type of geothermal fields mentioned above. Paleostress inversion analysis based on basin-bounding active faults and active extensional cracks along the travertine deposits shows that the AAG has been deformed under the control of multidirectional extension, with E-W and NE-SW to NW-SE orientations since Plio-Quaternary time. These types of extension are directly related with the linkage of cross faults that oriented at high-angle to the strike of NW-SE-trending major breakaway fault of AAG. Field-based studies also reveals that geothermal fields in AAG develops on the interactions of these active faults on the extensional domain type geothermal play without active volcanism coming to the surface.
\end{abstract}

\section{Batı Anadolu'da Genişleme Alanı Tipi Jeotermal Ortamın Varlığına Dair Yapısal Veriler: Afyon-Akşehir Grabeni'nden Örnek Bir Çalışma}

Öz

Akşehir-Simav Fay Sistemi'nin güneydoğu bölümünü temsil eden Afyon-Akşehir Grabeni (AAG), Batı Anadolu'daki aktif çöküntü alanlarından birisidir. KB-GD uzanımı AAG'nin batı bölümü Erkmen, Gecek, Gazlıgöl gibi diri normal faylar ile kontrol edilmektedir. $130^{\circ} \mathrm{C}^{\prime}$ ye varan rezervuar su sıcaklıkları ile bu bölgedeki en önemli jeotermal sahalar olan Ömer-Gecek ve Gazlıgöl Jeotermal sahaları sırasıyla Gecek

\section{Anahtar kelimeler}

Afyon Akşehir Grabeni; Jeotermal ortam;

Genişleme alanı; Batı Anadolu ve Erkmen Fayları ile Gazlıgöl ve Yarımca faylarının kesişim alanlarında yer almaktadır. Bölgede yüzlek veren jeolojik birimler, birbirlerinden uyumsuzlukla ayrılan Afyon Metamorfik Zonu'na ait Mesozoyik kayaçlar (rezervuar birim), Miyosen yaşlı volkano-sedimanter ve volkanik birimler (örtü birimi) ile Kuvaterner yaşlı alüvyal-flüvyal ve travertenlerden oluşan modern havza dolgularından oluşmaktadır. Bu çalışma, yukarıda bahsedilen jeotermal sahaların ortam tipini, jeolojik haritalama ve yapısal jeoloji gibi saha çalışmalarını içeren metodlar kullanılarak tanımlamayı amaçlamaktadır. Havzayı sınırlayan fay düzlemleri üzerinde yapılan paleostres analizleri ve faylar üzerinde ölçülen güncel açılma çatlakları, AAG'nin Pliyo-Kuvaterner'den beri, D-B ve KD-GB'dan KB-GD yönüne kadar değişiklik gösteren çok yönlü genişlemeli tektonizma etkisinde şekillendiğine işaret etmektedir. Genişleme tipi, AAG'nin KB-GD uzanımlı ana graben fayı ile bu faya yüksek açılı uzanan çapraz fayların bağlantıları ile ilişkilidir. Arazi 
bazlı çalışmalar, AAG içerisindeki jeotermal sahaların yüzeye gelmiş aktif volkanizma olmaksızın diri fayların kesişim noktalarında gelişen genişleme alanı tipi jeotermal ortamlara işaret ettiğini göstermektedir.

\section{Introduction}

The neotectonic structures of Anatolia have been shaped by deformation model which is affected by the westward tectonic escape of the Anatolian block, core complex formation, subduction related slab edge processes and backarc spreading as a result of collision between African, Arabian and Eurasian plates, in the Aegean region (Figure 1a) (e.g. Dewey and Sengör, 1979; Şengör et al., 1985; Bozkurt, 2001; Biryol et al., 2011). As a result, the Western Anatolian Extensional Province (WAEP), is currently experiencing an approximately $\mathrm{N}-\mathrm{S}$ continental extension and contains major depression areas with geothermal potentials such as Gediz, Büyük Menderes, Denizli and Afyon-Akşehir grabens (Dewey and Şengör 1979; Şengör and Yılmaz 1981; Şengör et al., 1985; Seyitoğlu and Scott 1991; Yılmaz et al., 2000; Bozkurt 2001; Sözbilir 2005; Özkaymak et al., 2013, Figure 1b). Extensional domain type geothermal plays such as Western Turkey are dominantly controlled by fault or faultleakage (Moeck, 2014). Because convection or fluid circulations occurs along these faults, geometry and stress modelling of the faults are essential in order to exploration for geothermal potentials. On the other hand, although some geological circumstances such as reservoir temperature, enthalpy, hydrogeology and exergy of these geothermal fields have been well analyzed in WAEP (e.g. Şimşek, 2003; Gemici and Tarcan, 2003; Öztürk et al., 2007; Erkan, 2015; Mertoğlu et al., 2015), the studies on structural controls and geothermal play types of them are quite rare (e.g. Şimşek, 1997; Pfister et al., 1998; Faulds et al., 2009).

Aksehir-Simav Fault System (ASFS) is one of the most active neotectonics structures in the WAEP and contains many geothermal fields between Ilgın and Balıkesir cities (Figure 1). Some of them are located in WNW-ESE-trending and approximately 150-km-long Afyon-Akşehir Graben (AAG) which represent the southeastern part of the ASFS.

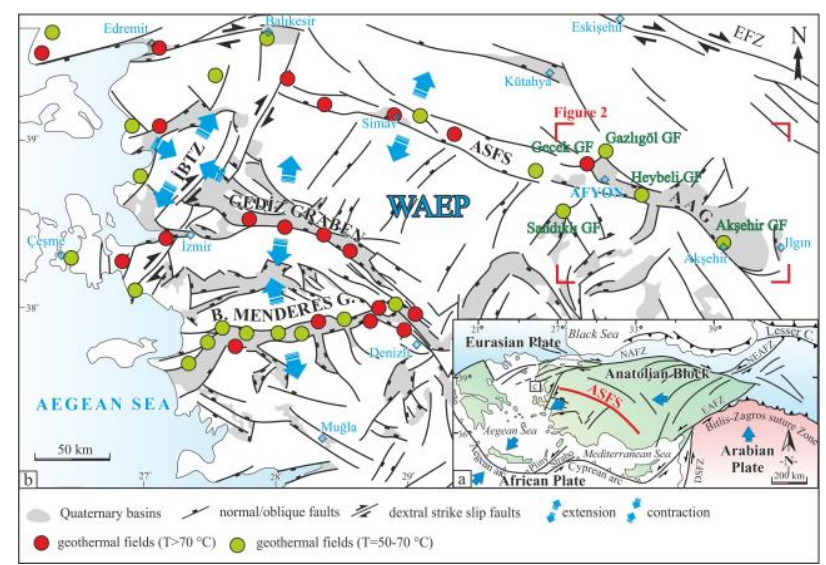

Figure 1. a) Tectonic outline of the eastern Mediterranean area (compiled from Özkaymak, 2015). Abbreviations: ASFS, Akşehir-Simav Fault System; DSFZ, Dead Sea Fault Zone; EAFZ, East Anatolian Fault Zone; NAFZ, North Anatolian Fault Zone; NEAFZ, Northeast Anatolian Fault Zone. b) Simplified map showing the major active basins and geothermal fields in western Anatolia (compiled from Faulds et al., 2009; Özkaymak, 2015; Mertoğlu et al., 2015). Abbreviations: IBTZ: izmir-Balıkesir Transfer Zone; AAG: Afyon-Akşehir Graben; WAEP: West Anatolian Extensional Province; EFZ: Eskişehir Fault Zone

Gazlıgöl, Ömer-Gecek, Heybeli and Akşehir geothermal fields have the most known geothermal springs. Gazlıgöl and Ömer-Gecek geothermal fields are located in the Afyon Basin (northwestern part of the $A A G$ ) and contain reservoirs of water with maximum temperatures of $70^{\circ} \mathrm{C}$ and $130^{\circ} \mathrm{C}$, respectively. Geothermal well location and temperature data are taken from Afyon Geothermal Facilities Tourism Ind. Trade Incorporated Business (AFJET). This study presents new field evidence, including geologic mapping, geomorphologic and 
structural analysis of the Gazlıgöl and Ömer-Gecek geothermal fields, to evaluate structural features of their geothermal play types.

\section{Geological Setting}

\subsection{Geology of the Study Area}

Afyon-Akşehir Graben is an approximately $150 \mathrm{~km}$ long, 4-20 km wide NW-SE-trending active depression which is controlled by a numerous active dip/oblique slip normal fault segments (Koçyiğit, 1984; Koçyiğit et al., 2000; Emre et al., 2011; Özkaymak et al., 2017 and 2019). The length of these faults range from 8 to $29 \mathrm{~km}$, with an average length of about $15 \mathrm{~km}$ (Duman et al., 2018; Emre et al., 2018). The historical and instrumental earthquake records indicate the existence of large number of earthquakes that created surface ruptures in this system. The latest one occurred on the Sultandağı Fault with a magnitude of 6.3103 February 2002) and caused a 26-km-long surface rupture in the middle part of the graben (Figure 2) (Yürür et al., 2002; Tan et al., 2008).

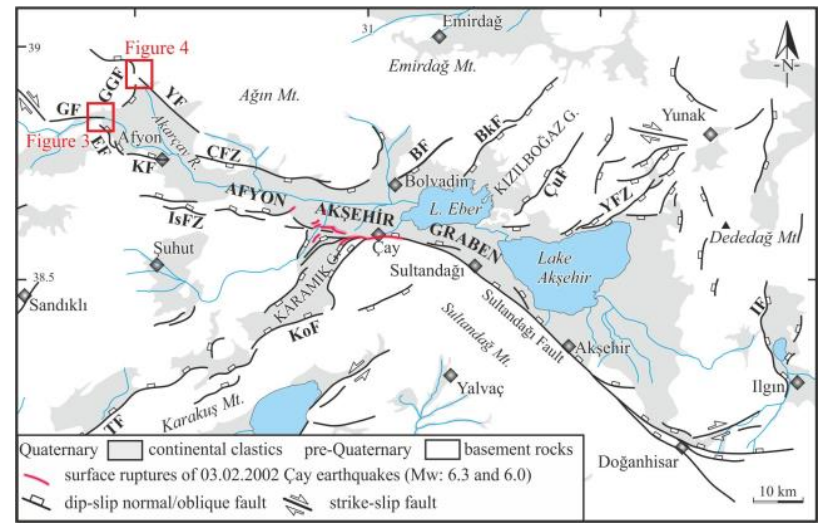

Figure 2. The active fault map of study area (compiled from Emre et al. 2011; Özkaymak et al. 2017) Abbreviations: GF: Gecek Fault; GGF: Gazlıgöl Fault; EF: Erkmen Fault; YF: Yarımca Fault; KF: Karahisar Fault; ÇFZ: Çobanlar Fault Zone; IsFZ: Işıklar Fault Zone; BF: Bolvadin Fault; BkF: Büyük Karabağ Fault; ÇuF; Çukurcak Fault; YFZ: Yunak Fault Zone; IF: Ilgın Fault; KoF: Kocbeyli Fault; TF: Tatarlı Fault.

The western sector of the AAG is controlled by active normal faults, namely Erkmen Fault, Gecek Fault, Gazlıgöl Fault, Karahisar Fault and Yarımca Fault. Gazlıgöl and Ömer-Gecek Geothermal fields are located in the western part of the graben, where the Holocene deposits and basement rocks are tectonically juxtaposed along the mountain fronts.

\section{2. Ömer-Gecek Geothermal Field}

Basement rocks in the study area are represented by rocks of Afyon Zone which was metamorphosed under blueschist facies conditions during late Cretaceous and early Cenozoic times (Candan et al., 2005; Pourteau et al., 2010 and 2013). The unit is composed of moderately folded and jointed schist and marbles with quartzite veins. Metamorphic rocks of the Afyon Zone are unconformably overlain by the Miocene-Pliocene sequence which starts with the terrestrial deposits representing the polygenic conglomerate and mudstone alternation. Then, grades upward into volcano-sedimentary deposits comprising of whitish-grey tuffite and agglomerate clasts. On top of this unit is composed of trachy-andesitic lava and volcanoclastic rocks, consisting tuff and agglomerate. The thickness of lava varies between 80 and $100 \mathrm{~m}$ (Yıldız et al., 2010). The Afyon Volcanics were previously dated by $\mathrm{Ar} / \mathrm{Ar}$ method yielding age ranging from 15.5 to 8.6 Ma (Prelevic et al., 2012; Akal et al., 2013). The uppermost part of the succession is represented by cream-beige coloured silicic and clay altered limestone. The sequence is unconformably overlain by the Quaternary modern basin fills consisting of alluvial, colluvial, fluvial and travertine deposits.

Ömer-Gecek geothermal field is located in the northwestern part of the Afyon Basin consisting of four geothermal springs, namely, Ömer, Gecek, Uyuz and Kızık springs. Structures shaping the northwestern side of basin have dominantly dip-slip normal fault character. Several NNW-SSE and NNESSW-trending dip-slip normal faults which cut mostly the basement rocks were mapped in the field (Figure 3). These faults also represent the structural contact between Miocene-Pliocene sequence and the pre-Neogene basement rocks to the north. The northern boundary of the Afyon Basin is represented by NE-SW-trending and southeast dipping Gecek fault. Slip lines with an average rake of $78^{\circ} \mathrm{E}$ indicate the normal behaviour on the $\mathrm{E}-\mathrm{W}$ - 
striking fault planes on site 1 (Figure 3). Along the boundary fault, Miocene-Pliocene terrestrial sediments and recent alluvial are juxtaposed. A few northwest dipping normal fault segments cut Quaternary travertines and forms step-like geometry around Uyuz spring (Figure 3).

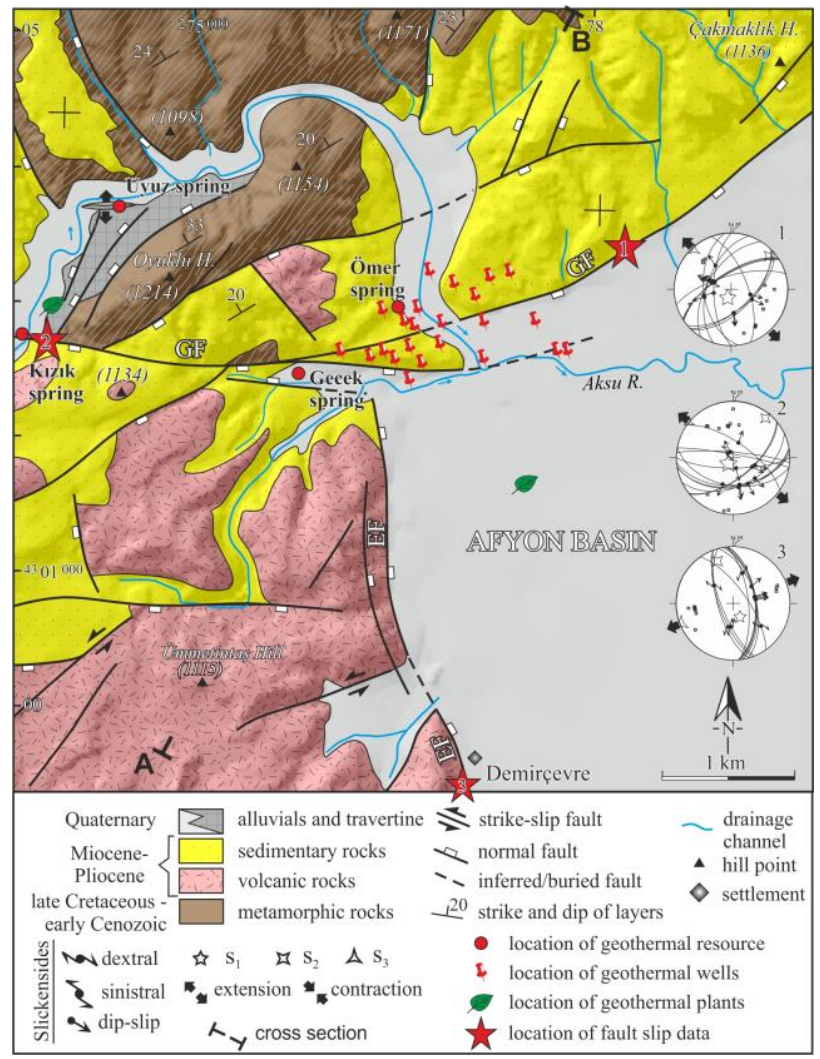

Figure 3. Detailed geologic map of the Ömer-Gecek geothermal field. Note that the results of kinematic analysis of faults are shown on eastern side of the figure. Geothermal well location and temperature data are taken from Afyon Geothermal Facilities Tourism Ind. Trade Incorporated Business (AFJET). Abbreviations: GF: Gecek Fault; EF: Erkmen Fault

Here, E-W-trending fissure-ridge-type travertine formations are exposed on the basinward fault splay. Western border of the Afyon Basin is controlled by a NNE-SSW-trending and east dipping Erkmen Fault which exhibits well preserved slip surfaces indicating $\mathrm{N} 5^{\circ} \mathrm{W}$ striking normal faulting with a rake of $86^{\circ}$ at the site 3 . Around Demirçevre town, volcanic rocks cover wide areas on the footwall of the Erkmen Fault while hangingwall is made up of alluvial fluvial sediments. Gecek spring is located on the junction of Erkmen and Gecek faults at the northwestern corner of the Afyon Basin.

\subsection{Gazlıgöl Geothermal Field}

Gazlıgöl geothermal field is located in the northeastern part of the Afyon Basin. Many fault splays were mapped both N-S and NW-SE associated with two different fault zones, namely Gazlıgöl and Yarımca faults which merge in the Gazlıgöl urban area (Figure 4).

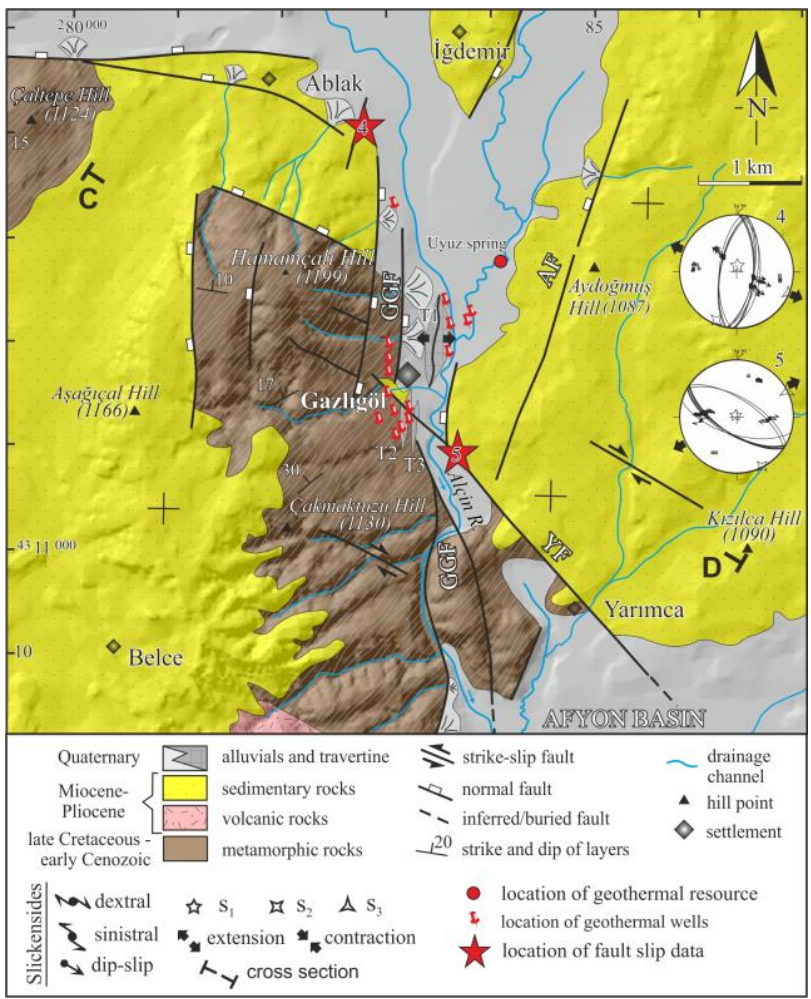

Figure 4. Detailed geologic map with kinematic analysis results of the Gazlıgöl geothermal field. Geothermal well location and temperature data are taken from Afyon Geothermal Facilities Tourism Ind. Trade Incorporated Business (AFJET). Abbreviations: GGF: Gazlıgöl Fault; YF: Yarımca Fault; AF: Aydoğmuş Fault.

These faults also control the northeast border of Afyon Basin. Field studies show that Gazlıgöl Fault bifurcated and cuts the metamorphic basement rocks to the south of the study area. Around the Gazlıgöl city center, N-S directed mountain front exhibits prominent linearity and well-developed alluvial fan deposits. Some well-preserved fault planes are exposed in a road cut, in the north of the 
study area and show fault planes dipping in the range of $56^{\circ}-67^{\circ}$ with rakes of $70^{\circ}-75^{\circ}$. The basinbounding Yarımca Fault exhibits well preserved slip data indicating $\mathrm{N} 50^{\circ} \mathrm{W}$ striking oblique faulting with a rake of $50^{\circ}$ indicating both normal and dextral slip component at the site 5. The Yarımca Fault also bordered the Miocene-Pliocene sediments. In the study area, Alçin river flows on the N-S-directed structural corridor in a south direction towards to the Afyon Basin. Two geological cross section were measured in the field in order to show geological setting including fault geometry, heat source, heat migration pathway, reservoir and cover units (Figure 5).

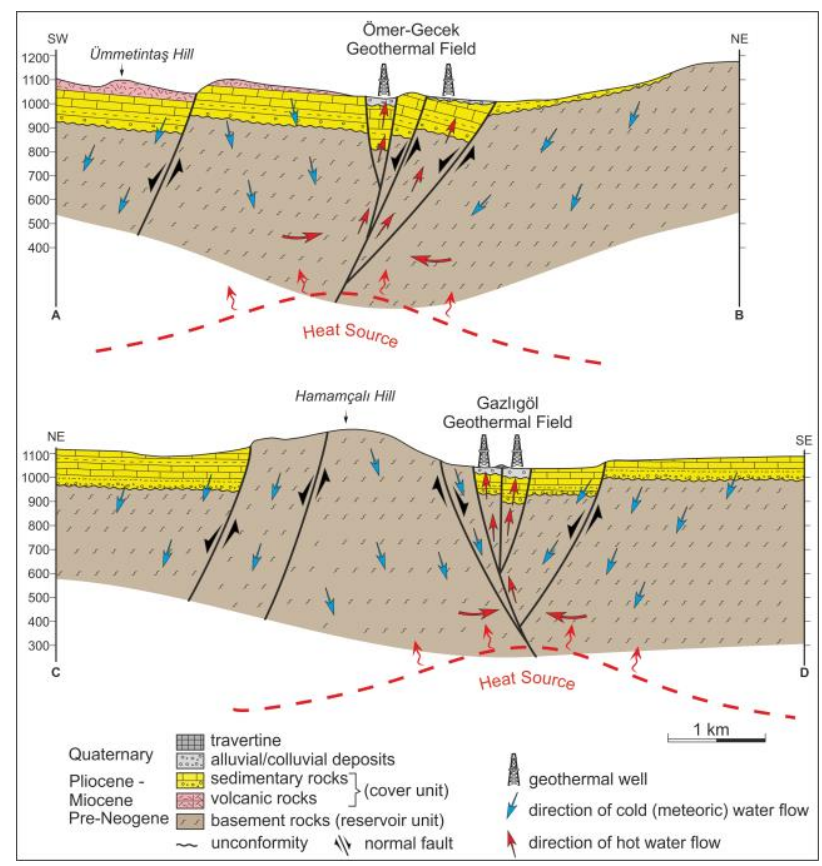

Figure 5. Geologic cross section showing stratigraphic and structural relationships of fault-controlled geothermal fields in Afyon Basin. See Figs. 3 and 4 for the location of cross sections.

Three N-S-trending fissure-ridge-type travertine formations are exposed along these faults. The longest ridge ( $\mathrm{T} 1$, Figure 4 ) is about $1 \mathrm{~km}$ and mapped in the northeast of the city center while others (T2 and T3) are about $500 \mathrm{~m}$ long outcropping in the southern part of the city center. $\mathrm{T} 2$ and $\mathrm{T} 3$ are cut and displaced by Yarımca Fault. Laterally offset is up to about 20 meters along the fault, providing strong evidence for right lateral displacement. Normal character of Yarımca Fault with a right lateral component of motion is also evidenced by measuring the fault-slip data (see, the section 2.3). Vertical veins in central part of the ridge can be seen along the $\mathrm{T} 1$ in N-S direction. Compound veins of up to $50 \mathrm{~cm}$ wide are also measured in the central part (Figure 6).

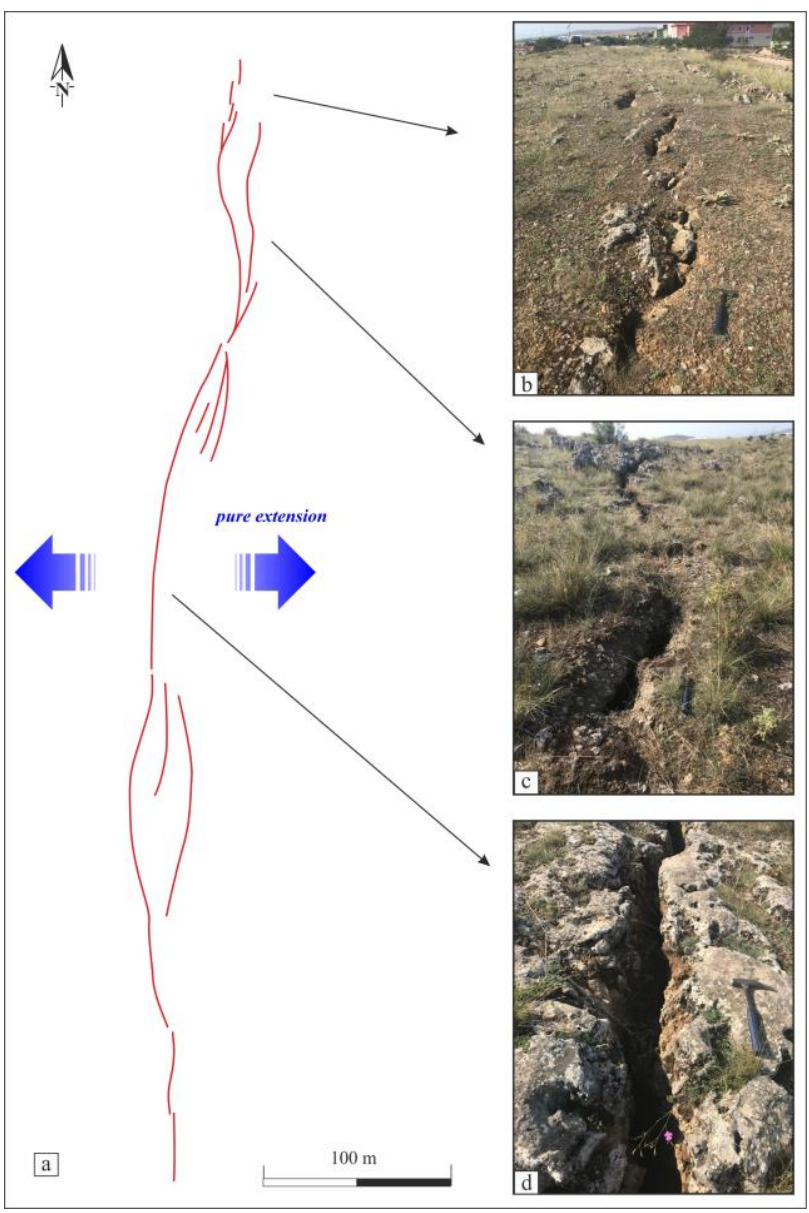

Figure 6. a) Extensional crack geometry of the Gazlıgöl Travertine (T1, see, Figure 3 for the location). $b, c, d)$ Field photographs of the crack.

Extensional fractures on ridge show bifurcating pattern and are mostly left stepping. Measured strikes are in between $\mathrm{N} 15^{\circ} \mathrm{W}$ and $\mathrm{N} 15^{\circ} \mathrm{E}$ while the average strike is $\mathrm{N}-\mathrm{S}$.

\subsection{Kinematic Analysis of Fault-slip Data}

During the field studies, we have studied the stress field orientations of mapped faults in order to determine the kinematic framework of faulting in Afyon Basin. Five locations were identified where the sense of Quaternary slip along brittle faults can be determined. The sense of movement along the faults was deduced from kinematic indicators, 
including displaced marker horizons, right-stepping, riedel shears and corrugations. Fault-slip data were analyzed using the stress inversion method of Angelier (1984, 1991, 1994), and then computed using software developed by Hardcastle and Hills (1991). Four components of the reduced stress tensor were extracted from the fault-slip data: the directions of the three principal stresses $(\sigma 1>\sigma 2>$ $\sigma 3)$ and the relative magnitudes for the principal stress axes, expressed by the axial ratio $\varphi=(\sigma 2-$ $\sigma 1) /(\sigma 3-\sigma 1)$, with $0<\varphi<1$ (Angelier, 1994). The stress regime is determined by the nature of the vertical stresses: extensional when $\sigma 1$ is vertical, strike-slip when $\sigma 2$ is vertical and compressional when $\sigma 3$ is vertical. Delvaux et al. (1997) suggested that the stress regimes also vary by function of the stress ratio, which ranges from 0 to 1 : radial extension ( $\sigma 1$ vertical, $0<\varphi<.25$ ), pure extension ( $\sigma 1$ vertical, $.25<\varphi<.75$ ), transtension ( $\sigma 1$ vertical, $.75<\varphi<1$ or $\sigma 2$ vertical, $1>\varphi>.75$ ), pure strikeslip ( $\sigma 2$ vertical, $.75>\varphi>.25$ ), transpression ( $\sigma 2$ vertical, $.25>\varphi>0$ or $\sigma 3$ vertical, $0<\varphi<.25$ ), pure compression ( $\sigma 3$ vertical, $.25<\varphi<.75$ ) and radial compression ( $\sigma 3$ vertical, $.75<\varphi<1$ ).
The computed results of fault slip measurements along the Gecek Fault define steeply plunging $\sigma 1$ axes $\left(77^{\circ}\right.$ and $\left.79^{\circ}\right)$, but gently plunging $\sigma 2$ axes $\left(11^{\circ}\right.$ and $\left.12^{\circ}\right)$ and $\sigma 3$ axes $\left(06^{\circ}\right.$ and $\left.00^{\circ}\right)$ at site 1 and 2 . The results suggest that the normal faulting is consistent with a NW-SE pure extensional stress regime $(\varphi=0,254-0,304)$ (Figure 3 and Table 1 ). Site 3, comprising 10 fault-slip measurements from Erkmen Fault indicate a NE-SW pure extensional tectonic regime. The calculated principles stress axes, $\sigma 1, \sigma 2$, and $\sigma 3$ have attitudes $153^{\circ} / 68^{\circ}$, $340^{\circ} / 22^{\circ}$ and $249^{\circ} / 22^{\circ}$, respectively. The computed results of fault slip measurements along the Gazlıgöl Fault (site no:4) (Figure 4 and Table 1) define relatively steeply dipping $\sigma 1$, plunging at $81^{\circ}$, whereas the $\sigma 2$ and $\sigma 3$ axes are almost horizontal plunging at $09^{\circ}$ and $02^{\circ}$. The stress field orientations along the Gazlıgöl fault suggest an approximately NW-SE-directed extension. Along the strike of Yarımca Fault, the computed results define an approximately vertical $\sigma 1$ plunging at $87^{\circ}$ and almost horizontal $\sigma 2$ and $\sigma 3$ axes, plunging at $03^{\circ}$ and $00^{\circ}$. The result suggests a NE-SW pure extension (Figure 4 and Table 1).

Table 1. Results of paleostress analysis from measurements of slickensides in the study area (see Figure 3 and 4 for locations which are showed as red filled stars). Abbreviations: Max ANG: Maximum misfit angle.

\begin{tabular}{lllllllll}
\hline no & $\begin{array}{l}\text { nature of } \\
\text { fault }\end{array}$ & fault name & $\boldsymbol{\sigma}_{\mathbf{1}}$ & $\boldsymbol{\sigma}_{\mathbf{2}}$ & $\boldsymbol{\sigma}_{\mathbf{3}}$ & $\boldsymbol{\varphi}$ & $\begin{array}{l}\text { Max } \\
\text { ANG }\end{array}$ & Stress regime \\
\hline 1 & normal-slip & Gecek & $202 / 77$ & $048 / 12$ & $317 / 06$ & 0,304 & 12 & Pure extension \\
2 & normal-slip & Gecek & $219 / 79$ & $039 / 11$ & $309 / 00$ & 0,254 & 22 & Pure extension \\
3 & normal-slip & Erkmen & $153 / 68$ & $340 / 22$ & $249 / 02$ & 0,655 & 10 & Pure extension \\
4 & normal-slip & Gazlıgöl & $007 / 81$ & $203 / 09$ & $112 / 02$ & 0.552 & 13 & Pure extension \\
5 & oblique-slip & Yarımca & $326 / 87$ & $153 / 03$ & $063 / 00$ & 0.708 & 06 & Pure extension \\
\hline
\end{tabular}

\section{Discussion and Conclusion}

Active extensional tectonic in Afyon Basin is documented by field-based studies including geological mapping, geomorphologic and structural analysis of graben bounding faults to identify structural features of play type of geothermal fields. Mapping studies clearly indicate that structures shaping the northwestern side of the Afyon Basin have dominantly dip-slip normal fault character. These active faults also responsible for the graben formation. Besides this, the computed results of fault slip measurements along the graben bounding faults suggest NE-SW and NW-SE-directed pure extension. On the other hand, fissure-ridge-type travertine formations on Gecek and Gazlıgöl Faults prove the existence of $\mathrm{N}-\mathrm{S}$ and E-W directed extensional tectonics, respectively. These results indicate the multidirectional extension stress field in N-S, E-W, NE-SW and NW-SE directions in Afyon Basin have been formed since Plio-Quaternary time. Multidirectional extensional regime in western Anatolia has been subject of many studies (e.g. 
Bozkurt and Mittwede, 2005; Bozkurt and Sözbilir, 2006; Rojay et al., 2012; Özkaymak et al., 2017; Özkaptan et al., 2018). Such type of extension is attributed to stress permutations between $\sigma 2$ and $\sigma 3$ in transfer zones in southwestern Anatolia by Bozkurt and Sözbilir (2006). The computed results of fault slip measurements in Afyon Basin also shows scattered patterns of $\sigma 2$ and $\sigma 3$ (Table 1). According to this study, these type of extension are directly related with the linkage of cross faults (Figure 5 and 7) that oriented at high-angle to the strike of NW-SE-trending major breakaway fault of AAG. Field-based studies reveal that geothermal fields in AAG develops on the interactions of these active faults on the extensional domain type geothermal play without active volcanism coming to the surface. Similar tectonic models are also proposed for Kızıldere (Turkey), Bradys (Nevada/USA), Soulz-sous-Forets (France), Olkaria (Kenya) geothermal fields (Moeck et al., 2014). Fault intersections between several normal faults in AAG cause to highly fractured rocks by connecting the structures and cause the suitable environment to fluids flow (Figure 7).

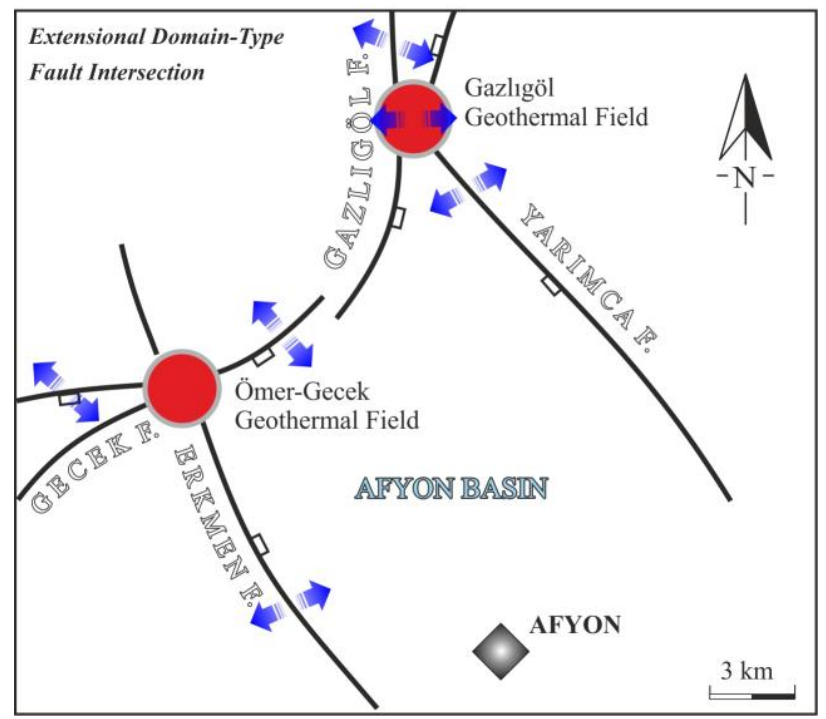

Figure 7. Structural setting of geothermal play for Gazlıgöl and Ömer-Gecek geothermal fields

\section{Acknowledgments}

This study is supported by Afyon Kocatepe University Scientific Research (BAP) Project of 18.KARIYER.189 and 17.KARIYER.207. We are grateful to Arda Özkaymak and Mertkan Osman Geçievi for their helps during the field studies.

\section{References}

Akal, C., Helvacı, C., Prelević D. and van Den Bogaard, P., 2013. High-K volcanism in the Afyon region, western Turkey: from Sioversaturated to Si-undersaturated volcanism. International Journal of Earth Sciences, 102 (2), 435-453.

Angelier, J., 1984. Tectonic analysis of fault slip data sets. Journal of Geophysical Research, 89, 5835-5848.

Angelier, J., 1991. Inversion of field data in fault tectonics to obtain regional stress. III: A new rapid direct inversion method by analytical means. Geophysical Journal International, 103, 363-376.

Angelier, J., 1994. Fault slip analysis and paleostress reconstruction, In P. L. Hancock (Ed.), Continental deformation, Oxford: Pergamon Press ,53-100.

Biryol, C.B., Beck, S.L., Zandt, G. and Özacar, A.A., 2011. Segmented African lithosphere beneath the Anatolian region inferred from teleseismic P-wave tomography. Geophysical Journal International, 184, 1037-1057.

Bozkurt, E., 2001. Neotectonics of Turkey-A synthesis. Geodinamica acta, 14 (1-3), 3-30.

Bozkurt, E. and Mittwede, S.K., 2005. Introduction: Evolution of continental extensional tectonics of western Turkey. Geodinamica Acta 18 (3-4) 153-165.

Bozkurt, E. and Sözbilir, H., 2006. Evolution of the large-scale active Manisa Fault, southwest Turkey: Implications on fault development ve regional tectonics. Geodinamica Acta, 19 (6), 427-453.

Candan, O., Çetinkaplan, M., Oberhansli, R., Rimmele, G. and Akal, C., 2005. Alpine high- 
P/low-T metamorphism of the Afyon Zone and implications for the metamorphic evolution of Western Anatolia, Turkey. Lithos, 84, 102-124.

Delvaux, D., Moeys, R., Stapel, G., Petit, C., Levi, K., Miroshnichenko, A., Ruzhich, V. and Sankov, V., 1997. Paleostress reconstructions and geodynamics of the Baikal region, Central Asia Part II: Cenozoic rifting. In S. Cloetingh, M. Fernandez, J. A. Munoz, W. Sassi, and F. Horvath (Eds.), Structural controls on sedimentary basin formation, Tectonophysics, 282, 1-38.

Dewey, J. F., and Şengör, A. M. C., 1979. Aegean and surrounding regions: Complex multiplate and continuum tectonics in a convergent zone. Geological Society of America Bulletin, 90, 8492.

Duman, T.Y., Çan, T., Emre, Ö., Kadirioğlu, F.T., Başarır, Baştürk, N., Kılıç, T., Arslan, S., Özalp, S., Kartal, R.F., Kalafat, D., Karakaya, F., Eroğlu, Azak, T., Özel, N.M., Ergintav, S., Akkar, S., Altınok, Y., Tekin, S., Cingöz, A. and Kurt, A.I.,, 2018. Seismotectonics database of Turkey. Bulletin of Earthquake Engineering, 16 (8), 3277-3316.

Emre, Ö., Duman, T. Y., Özalp, S., Olgun, Ş. and Elmacl, H., 2011. 1:250.000 scale active fault map series of Turkey, Afyon (NJ 36-5) Quadrangle, Serial number: 16, General Directorate of Mineral Research and Exploration, Ankara, Turkey.

Emre, Ö., Duman, T.Y., Özalp, S., Şaroğlu, F., Olgun, Ş., Elmacı, H. and Çan, T., 2018. Active fault database of Turkey. Bulletin of Earthquake Engineering, 16 (8), 3229-3275.

Erkan, K., 2015. Geothermal investigations in western Anatolia using equilibrium temperatures from shallow boreholes. Solid Earth, 6, 103-113.

Faulds, J.E., Bouchot, V., Moeck, I., and Oğuz, K., 2009. Structural controls of geothermal systems in western Turkey: A preliminary report. Geothermal Resources Council Transactions, 33, 375-383.

Gemici, U. and Tarcan, G., 2003. Hydrogeochemistry of the Simav geothermal field, western Anatolia, Turkey. Journal of Volcanology and Geothermal Research, 116 (34), 215-233.

Hardcastle, K. C. and Hills, L. S., 1991. BRUTE3 and SELECT: Quick Basic 4 programmes for determination of stress tensor configurations and separation of heterogeneous populations of fault slip data. Computers and Geosciences, 17, 23-43.

Koçyiğit, A., 1984. Güneybatı Türkiye ve yakın dolayında levha içi yeni tektonik gelişim. Türkiye Jeoloji Kurumu Bülteni, 27 (1), 1- 15 (in Turkish).

Koçyiğit, A., Ünay, E. and Saraç, G., 2000. Episodic graben formation and extensional neotectonics regime in west Central Anatolia and the Isparta Angle: a case study in the Akşehir-Afyon Graben, Turkey. Geological Society of London Special Publication, 173, 405421.

Mertoğlu, O., Simsek, S., and Başarır, N., 2015. Geothermal Energy Use, Country Update for Turkey. Proceedings, European Geothermal Congress 2016, Strasbourg, France, 1-10.

Moeck, I.S., 2014. Catalog of geothermal play types based on geologic controls. Renewable and Sustainable Energy Reviews, 37, 867-882.

Özkaptan, M., Kaymakcı, N., Langereis, C. G., Gülyüz, E., Özacar, A. A., Uzel, B., and Sözbilir, $\mathrm{H}$. 2018. Age and kinematics of the Burdur Basin: Inferences for the existence of the Fethiye Burdur Fault Zone in SW Anatolia (Turkey). Tectonophysics, 744, 256-274.

Özkaymak, Ç., 2015. Tectonic analysis of the Honaz Fault (western Anatolia) using geomorphic indices and the regional 
implications. Geodinamica Acta, 27 (2-3), 110129.

Özkaymak, Ç., Sözbilir, H., and Uzel, B., 2013. Neogene-Quaternary evolution of the Manisa Basin: Evidence for variation in the stress pattern of the İzmir-Balıkesir Transfer Zone, western Anatolia. Journal of Geodynamics, 65, 117-135.

Özkaymak Ç., Sözbilir, H., Tiryakioğlu, ì. and Baybura, T., 2017. Geologic, Geomorphologic and Geodetic Analyses of Surface Deformations Observed in Bolvadin (AfyonAkşehir Graben, Afyon). Geological Bulletin of Turkey, 60, 169-188.

Özkaymak, Ç., Sözbilir, H., Geçievi, M.O. and Tiryakioğlu, İ., 2019. Late Holocene coseismic rupture and aseismic creep on the Bolvadin Fault, Afyon Akşehir Graben, Western Anatolia. Turkish Journal of Earth Science, 28, 787-804.

Öztürk, H.K., Atalay, Ö., Yılancı, A. and Hepbaşlı, A., 2007. Energy and Exergy Analysis of Kizildere Geothermal Power Plant, Turkey. Energy Sources, Part A, 28 (15), 1415-1424.

Pfister, M., Rybach, L., and Şimşek, S., 1998. Geothermal reconnaissance of the Marmara Sea region (NW Turkey); surface heat flow density in an area of active continental extension. Tectonophysics, 291 (1-4), 77-89.

Pourteau, A., Candan, O. and Oberhansli, R., 2010. High-Pressure metasediments in central Turkey: constraints on the Neotethyan closure history. Tectonics, 29, TC5004.

Pourteau, A., Sudo, M., Candan, O., Lanari, P., Vidal, O. and Oberhänsli, R., 2013. Neotethys closure history of Anatolia: insight from 40Ar39Ar geochronology and P-T estimation in high-pressure metasediments. Journal of Metamorphic Geology, 31, 585-606.

Prelević D., Akal, C., Foley, S.F., Romer, R.L., Stracke, A. and van Den Bogaard, P., 2012. Ultrapotassic mafic rocks as geochemical proxies for postcollisional mantle dynamics of lithosphere: the case of SW Anatolia-Turkey. Journal of Petrol, 53, 1019-1055.

Rojay, B., Toprak, V., Demirci, C. and Süzen, L., 2005. Plio-Quaternary evolution of the Küçük Menderes Graben (Southwestern Anatolia, Turkey). Geodinamica Acta, 18, 317-331.

Seyitoğlu, G. and Scott, B., 1991. Late Cenozoic crustal extension and basin formation in west Turkey. Geological Magazine, 128, 155-166.

Sözbilir, H., 2005. Oligo-Miocene extension in the Lycian orogen: evidence from the Lycian molasse basin, SW Turkey. Geodinamica Acta, 18, 257-284.

Şengör, A.M.C. and Yılmaz, Y., 1981. Tethyan evolution of Turkey: a plate tectonic approach, Tectonophysics, 75, 181-241.

Şengör, A. M. C., Görür, N., and Şaroğlu, F., 1985. Strike-slip faulting and related basin formation in zones of tectonic escape: Turkey as a case study. In K. T. Biddle and N. Christie-Black (Eds.), Strike-slip deformation, basin formation and sedimentation Tulsa, Oklahoma. Society of Economic Paleontologists and Mineralogists Special Publication, 37, 227-264

Şimşek, S., 1997. Geothermal potential in northwestern Turkey, Active Tectonics of Northwestern Anatolia. The Marmara PolyProject (Edited by Schindler, C., and Pfister, M., 1997), vdf hochschulverlag AG ander ETH, Zurich, 111-123

Şimşek, S., 2003. Hydrogeological and isotopic survey of geothermal fields in the Buyuk Menderes Graben, Turkey. Geothermics, 32 (46), 669-678.

Tan, O., Tapırdamaz, M. C., and Yörük, A., 2008. The earthquakes catalogues for Turkey. Turkish Journal of Earth Sciences, 17, 405-418.

Yılmaz, Y., Genç, S.C., Gürer, O.F., Bozcu, M., Yılmaz, K., Karacık, Z., Altunkaynak, R. and 
Elmas, A., 2000. When did the western Anatolian grabens begin to develop? In: Bozkurt, E., Winchester, J.A., Piper, J.D.A. (Eds.), Tectonics and Magmatism in Turkey and the Surrounding Area. Geological Society of London Special Publications, 173, 353-384.

Yıldız, A., Kuşcu, M., Dumlupınar, İ., Arıtan, E. and Bağcl, M., 2010. The determination of the mineralogical alteration index and the investigation of the efficiency of the hydrothermal alteration on physicomechanical properties in volcanic rocks from Köprülü, Afyonkarahisar, West Turkey. Bulletin of Engineering Geology and the Environment, 69, 51-61.

Yürür, T., Köse, O., Demirbağ, H., Özkaymak, Ç. and Selçuk, L., 2003. Could the coseismic fractures of a lake ice reflect the earthquake mechanism? (Afyon earthquakes of 3 February 2002, Central Anatolia, Turkey). Geodinamica Acta, 16, 83-87. 